\title{
URBAN HOUSE PRICES AND BUSINESS ESTABLISHMENT IN MALAYSIA: A SECTORAL APPROACH
}

\author{
Hassan F. GHOLIPOUR ${ }^{1,}{ }^{*}$, Sabai KHIN ${ }^{2}$, Angela TAN-KANTOR ${ }^{3}$, Heath SPONG ${ }^{1}$ \\ ${ }^{1}$ School of Business, Western Sydney University, Sydney, Australia \\ ${ }^{2}$ School of Management, Universiti Sains Malaysia, Penang, Malaysia \\ ${ }^{3}$ Canberra Business School, Faculty of Business, Government and Law, University of Canberra, Canberra, Australia
}

Received 12 October 2020; accepted 30 August 2021

\begin{abstract}
The purpose of this study is to examine the long-run and short-run relationship between house prices and business formation in various industries. Using data from Malaysian states over the period of 2000-2016 and applying ARDL/PMG models, our results show that changes in house prices have a positive and significant association with business establishment in specific economic sectors, including manufacturing, wholesale and retail trade, information and communication, and financial and insurance in the long-run. However, the long-run relationship between house prices and business formation is negative and significant for electricity, gas, steam and air conditioning supply, construction, transportation and storage, accommodation and food service activities, and real estate industries. The short-run analysis indicates that there is a difference in the responses of business establishment in various industries to the changes in house prices.
\end{abstract}

Keywords: house prices, business formation, Malaysia, panel ARDL/PMG.

\section{Introduction}

The search for potential for synergies between the property market and business activity in the rest of the economy has attracted the focus of much research effort. In particular, there continues to be growing interest in the relationship between house prices and new business formation. Many of the existing studies in this literature have identified a positive relationship between changes in house prices and business start-ups. This positive relationship has been noted in a range of developed economies, including Australia (Connolly et al., 2015), France (Schmalz et al., 2017), Sweden (Berggren et al., 2019), the UK (Robson, 1996; Black et al., 1996) and in the US (e.g., Balasubramanyan \& Coulson, 2013; Corradin \& Popov, 2015; Harding \& Rosenthal, 2017; Adelino et al., 2015; Kerr et al., 2015).

Researchers often explain this positive relationship through two hypotheses: the housing wealth effect channel, and the housing collateral enhancement channel (Gholipour, 2020). The housing wealth effect channel hypothesis argues that "growing house prices increase the wealth levels of entrepreneurs and lead them to start new businesses" (Kerr et al., 2015, p. 3). Relatedly, the housing collateral channel contends that "rising housing prices in- crease the housing equity of residential property owners. This increases the potential borrowing capacity of creditconstrained entrepreneurs, allowing them to finance more entrepreneurial activity by using their housing equity" (Connolly et al., 2015, p. 115). In short, the premise of both hypotheses is that liquidity constraints are a deterrent to new business formation and that rising house prices can help potential entrepreneurs overcome this credit constraint (Hurst \& Lusardi, 2004) ${ }^{1}$.

While the studies drawn from developed economies provide a body of evidence in support of these two hypotheses, a number of studies in the context of developing economies (e.g., China and Iran) do not support the positive relationship between increases in property prices and business formation. In a recent study, Gholipour (2020) provides evidence that rises in house prices have suppressed industrial entrepreneurship in Iran (over the period of 2005-2016), and posits three negative channels: the property investment opportunity channel, the growth

\footnotetext{
1 Hurst and Lusardi (2004) find that a positive relationship between household wealth and business entry only exists for very wealthy households and not for households with wealth up to $\$ 200,000$.
}

${ }^{\star}$ Corresponding author. E-mail: h.fereidouni@westernsydney.edu.au 
of the property brokerage sector, as well as a "marriage crowd-out effect" (Gholipour, 2020). First, in the property investment opportunity channel, he argues that rises in house prices encourage potential entrepreneurs to transfer their investment funds away from industrial activities and into construction and real estate activities. Second, he argues that the development of the property brokerage sector resulting from the housing boom attracts many educated labour force participants to the real estate industry, which can possibly reduce the level of industrial entrepreneurship. Third, under the "marriage crowd-out effect", Gholipour (2020) notes that rises in residential property prices encourage individuals to save more to purchase houses (that is one of the main prerequisites for marriage). This increased focus on accumulating savings for the purposes of buying a home can undermine the incentive to develop a business in the industrial sector. Similarly, by using data from the Inter-Census Population Survey and the Chinese Family Panel Studies, Li and Wu (2014) find a negative link between house prices and entrepreneurial activities (through the housing investment opportunity and "marriage crowd-out effect" channels) in China.

In this study, we further investigate the association between house prices and business formation by examining the relationship between Malaysian house price indices (All House Price Index, Detached House Price Index, Terraced House Price Index and Semi-Detached House Price Index) and formation of businesses across 10 Malaysian states over the 2000-2016 period. We delve further into this relationship by incorporating a sectoral analysis that disaggregates our measurement of business formation into various sectors of the Malaysian economy such as manufacturing, construction, wholesale and retail trade, accommodation, and food service activities.

It is important to examine the effect of house prices on business establishments in various economic sectors because credit constraints faced by Malaysian firms vary between sectors. For example, according to the $2015 \mathrm{Ma}-$ laysia Enterprise Survey (World Bank, 2021), 19\%, 24\% and $21 \%$ of firms in the Garment, Services of motor vehicles, and Textiles sectors, respectively, indicated "access to finance" is a major and very severe obstacle to the operations of their businesses. On the other hand, only $8 \%$ of firms in the Wood and Electronics sectors mentioned that "access to finance" is such a major and severe obstacle to the operations of their establishments. The sub-sectoral analysis conducted in this study is further motivated by the findings of several studies which show that firms in some sectors face more difficulty in accessing finance than firms in other sectors (e.g., Manova, 2013; Braun, 2003). For example, Abraham and Schmukler (2017) show that small and medium enterprises (SMEs) in innovative sectors face more financial constraints than other sectors because financial institutions are unwilling to lend to unfamiliar sectors.

Our analysis is effective in uncovering further evidence that this sectoral approach does indeed demonstrate important variation between sectors. More specifically, by using the Pooled Mean Group estimator of Pesaran et al. (1999) for Autoregressive Distributed Lag models (ARDL/PMG), we provide empirical evidence that business establishment in different industries react differently to changes in house prices in Malaysia in the long-run and the short-run.

The contributions of this study to the literature on the relationship between property prices and business formation (and business start-up, self-employment, and entrepreneurship) are threefold. First, to the best of our knowledge, very little research has analysed the relationship between aggregate housing price indices (and sub-indices) and business registration within various economic sectors (Adelino et al., 2015; Berggren et al., 2019). Second, we focus on the case of Malaysia, which has been largely overlooked in this area of research. Given that the country has reliable data for business registration across states over time, Malaysia provides an interesting context to examine our research question. Indeed, a key policy agenda of the country is to promote entrepreneurship and start-up creation to fuel the economy and employment. SMEs play a significant role in Malaysia's economy and accounted for $38.3 \%$ and $17.2 \%$ of national outputs and exports, respectively, in 2018 (Department of Statistics Malaysia, 2019). Third, very few studies have decomposed the link between house prices and business formation into long-run and short-run components.

The rest of this article is structured as follows. Section 1 describes the data and variables. Section 2 presents the empirical model and describes the panel ARDL/PMG estimator. Section 3 reports and discusses findings of the long-run and short-run analyses. Last section concludes the paper and provides some implications.

\section{Data}

This study uses annual data from 10 Malaysian states covering the period 2000-2016. The states included in our dataset are Johor, Kedah, Kelantan, Melaka, Negeri Sembilan, Pahang, Perak, Pulau Pinang, Selangor and Terengganu. The choice of sample states and period of study is based on the availability of data. Data for Malaysia's house price indices within these states, including the three sub-indices (terraced, detached, and semi-detached ${ }^{2}$ ), is sourced from the National Property Information Centre [NAPIC] (2019). The NAPIC provides the detailed information required for the index calculation. It also provides sales data of residential properties that individuals purchase and sell in the 14 states and territories in Malaysia.

Given the data collection procedures of the national government body, we believe our samples provide a reasonable representation of houses sold in Malaysia. Furthermore, the size of the data set is significant, and includes an average of about 20,000 observations per quarter. The data include information on the location, physical,

\footnotetext{
2 We do not include High-Rise Unit Price Index in our analyses due to several missing values that undermine the value of the series.
} 
Table 1. Average annual growth rate (\%) of various house price indices in a set of Malaysian states (2000-2016) (source: NAPIC, 2019, Valuation and Property Services Department, Ministry of Finance Malaysia. http://napic.jpph.gov.my/portal)

\begin{tabular}{|l|c|c|c|c|}
\hline \multicolumn{1}{|c|}{ States } & $\begin{array}{c}\text { All house price } \\
\text { index }\end{array}$ & $\begin{array}{c}\text { Terraced house price } \\
\text { index }\end{array}$ & $\begin{array}{c}\text { Detached house price } \\
\text { index }\end{array}$ & $\begin{array}{c}\text { Semi-detached house } \\
\text { price index }\end{array}$ \\
\hline Johor & 4.04 & 3.93 & 4.21 & 4.79 \\
\hline Kedah & 5.32 & 5.01 & 6.14 & 5.88 \\
\hline Kelantan & 4.75 & 5.17 & 5.05 & 4.55 \\
\hline Melaka & 4.72 & 5.14 & 1.45 & 5.56 \\
\hline Negeri Sembilan & 5.19 & 5.34 & 4.84 & 6.96 \\
\hline Pahang & 6.69 & 6.39 & 7.63 & 6.23 \\
\hline Perak & 5.87 & 5.75 & 4.45 & 4.45 \\
\hline Pulau Pinang & 6.55 & 6.94 & 5.67 & 5.79 \\
\hline Selangor & 5.72 & 5.87 & 6.16 & 7.12 \\
\hline Terengganu & 6.75 & 6.64 & & \\
\hline
\end{tabular}

and legal characteristics of various types of houses sold (NAPIC, 2019) ${ }^{3}$. It is noteworthy that several researchers have utilized the NAPIC's data to analyse Malaysian housing market (e.g., Lean \& Smyth, 2013; Gholipour, 2013; Gholipour et al., 2017).

Table 1 shows the average annual growth rate of the aggregate house price index (with $2000=100$ ), and the average annual growth rate of price indices for terraced, detached, and semi-detached houses. As shown in Table 1, Pahang, Pulau Pinang and Terengganu states experienced strongest growth among the sample of states.

Data for the number of business registrations in each sector (and by individual state) are obtained from the Companies Commission of Malaysia (2020). Our sample only includes firms that are registered under the Registration of Business (ROB) category (and not the Registration of Company (ROC) category). The sample businesses are primarily small or medium size. There are two types of businesses that fall under ROB registration: Sole Proprietorship (a business wholly owned by a single owner) and Partnership (a business owned by at least two persons and not more than twenty partners) ${ }^{4}$. Businesses that fall under the ROB category are subject to personal tax (unlike ROC businesses which are subject to corporate tax $)^{5}$. As can be seen from Table 2, the top three states in terms of growth in business registration are Terengganu, Selangor, and Johor, while the Perak and Pulau Pinang state regions experienced the lowest growth rates. In our estimations, we use the ratio of the number of business registration in each sector by the total number of registrations to ensure

\footnotetext{
3 For details about The Malaysian House Price Index, please see Explanatory Notes in page 50 of NAPIC (2019).

4 See https://www.ssm.com.my/Documents/guidelines_for_ registration_of_new_business_05062018_0.pdf

5 See https://foundingbird.com/my/blog/company-registrationtype-in-malaysia
}

Table 2. Average of total number and average annual growth rate of business registration in a set of Malaysian states (20002017) (source: Companies Commission of Malaysia, 2020.

Available at https://www.ssm.com.my/Pages/Home.aspx\#)

\begin{tabular}{|l|c|c|}
\hline \multicolumn{1}{|c|}{ States } & $\begin{array}{c}\text { Number } \\
\text { of business } \\
\text { registration }\end{array}$ & $\begin{array}{c}\text { Growth (\%) } \\
\text { in business } \\
\text { registration }\end{array}$ \\
\hline Johor & 35,297 & 8.60 \\
\hline Kedah & 22,168 & 6.60 \\
\hline Kelantan & 16,452 & 7.20 \\
\hline Melaka & 10,343 & 7.40 \\
\hline Negeri Sembilan & 14,527 & 10.20 \\
\hline Pahang & 14,808 & 8.30 \\
\hline Perak & 18,535 & 5.70 \\
\hline Pulau Pinang & 18,522 & 6.00 \\
\hline Selangor & 73,894 & 10.90 \\
\hline Terengganu & 11,929 & 11.40 \\
\hline
\end{tabular}

we capture the size of each state ${ }^{6}$. A description of the variables and summary statistics for all variables is provided in Table 3, and the short-hand version of the sector names are listed there.

\section{Methodology}

We apply the ARDL/PMG model in our estimations of the key relationships. The model is suitable for our study since we are interested in understanding both the longrun and short-run impacts of changes in house prices on new business formation across Malaysian states over time (from 2000 to 2016). In addition, the application of the ARDL/PMG estimator in our empirical study is

\footnotetext{
6 Our estimation results do not change when we use the logarithm of number of business registration in each state as a dependent variable.
} 
Table 3. Description and summary statistics of variables (before transformation)

\begin{tabular}{|c|c|c|c|c|c|}
\hline Variable & Definition & Mean & Std. Dev. & Min & Max \\
\hline AGRICULTURE & $\begin{array}{l}\text { Share of agriculture, forestry, and fishing in total business } \\
\text { registration }\end{array}$ & 0.0708 & 0.0371 & 0.0140 & 0.1975 \\
\hline MANUFACTURING & Share manufacturing in total business registration & 0.0860 & 0.0522 & 0.0168 & 0.3011 \\
\hline UTILITY & $\begin{array}{l}\text { Share of electricity, gas, steam, and air conditioning supply in } \\
\text { total business registration }\end{array}$ & 0.0033 & 0.0032 & 0.0003 & 0.0172 \\
\hline WATER & $\begin{array}{l}\text { Share water supply; sewerage, waste management and } \\
\text { remediation activities in total business registration }\end{array}$ & 0.0037 & 0.0032 & 0.0001 & 0.0220 \\
\hline CONSTRUCTION & Share of construction in total business registration & 0.0932 & 0.0369 & 0.0279 & 0.2135 \\
\hline WHOLESALE & $\begin{array}{l}\text { Share of wholesale and retail trade; repair of motor vehicles } \\
\text { and motorcycles in total business registration }\end{array}$ & 0.4433 & 0.0686 & 0.3366 & 0.7402 \\
\hline TRANSPORT & $\begin{array}{l}\text { Share of transportation and storage in total business } \\
\text { registration }\end{array}$ & 0.0365 & 0.0179 & 0.0055 & 0.0811 \\
\hline ACCFOOD & $\begin{array}{l}\text { Share of accommodation and food service activities in total } \\
\text { business registration }\end{array}$ & 0.1906 & 0.0527 & 0.0530 & 0.3354 \\
\hline INFORMATION & $\begin{array}{l}\text { Share of information and communication in total business } \\
\text { registration }\end{array}$ & 0.0063 & 0.0048 & 0.0010 & 0.0267 \\
\hline FINANCE & $\begin{array}{l}\text { Share of financial and insurance/takaful activities in total } \\
\text { business registration }\end{array}$ & 0.0174 & 0.0129 & 0.0042 & 0.0943 \\
\hline REALESTATE & Share of real estate activities in total business registration & 0.0017 & 0.0012 & 0.0001 & 0.0056 \\
\hline PROFESSIONAL & $\begin{array}{l}\text { Share of professional, scientific, and technical activities in } \\
\text { total business registration }\end{array}$ & 0.0458 & 0.0236 & 0.0114 & 0.1163 \\
\hline HP_ALL & All house price index & 148.0865 & 47.6272 & 84.1000 & 280.7000 \\
\hline HP_TERRACED & Terraced house price index & 150.0753 & 48.8587 & 80.1000 & 290.0000 \\
\hline HP_DETACHED & Detached house price index & 143.4924 & 54.5483 & 83.4000 & 333.4000 \\
\hline HP_SEMIDETACHED & Semi-detached house price index & 150.6800 & 50.0450 & 91.4000 & 292.8000 \\
\hline
\end{tabular}

appropriate for our panel data setting because the number of years $(\mathrm{T})$ is larger than number of states $(\mathrm{N})$. Finally, as noted by Pesaran and Shin (1997, p. 16), "appropriate modification of the orders of the ARDL model is sufficient to simultaneously correct for the residual serial correlation and the problem of endogenous regressors".

The ARDL/PMG model takes the cointegration form of the simple ARDL model and adapts it for a panel setting by allowing the intercepts, short-run coefficients and cointegrating terms to differ across cross-sections (Pesaran et al., 1999). "ARDLs are standard least squares regressions that include lags of both the dependent variable and explanatory variables as regressors (Greene, 2008)" PMG estimator (Pesaran et al., 1997, 1999) is a technique to estimate nonstationary dynamic panels in which the parameters are heterogeneous across groups. The PMG estimator relies on a combination of pooling and averaging of coefficients (Blackburne \& Frank, 2007). That is, this estimator allows the intercept, short-run coefficients, and error variances to differ across the groups, but constrains the long-run coefficients to be equal across groups (Blackburne \& Frank, 2007).

\footnotetext{
7 See http://www.eviews.com/help/helpintro.html\#page/content/ ardl-autoregressive_Distributed_Lag_(ARDL)_Models.html
}

\section{Model}

Assume the long-run function

$$
B U S_{i t}=\theta_{0 t}+\theta_{1 t} H P_{i t}+\mu_{i}+\varepsilon_{i t},
$$

where: the number of states $i=1,2, \ldots, N$; the number of years $t=1,2, \ldots, T ; B U S_{i t}$ represents the dependent variable (ratio of business registration in each sector/total number of business registration); $H P_{i t}$ represents house price indices (in logarithmic form).

The ARDL dynamic panel specification of Equation (1) is

$$
B U S_{i t}=\delta_{10 i} H P_{i t}+\delta_{11 i} H P_{i, t-1}+\lambda_{i} B U S_{i, t-1}+\mu_{i}+\varepsilon_{i t} .
$$

The error correction reparameterization of Equation (2) is

$$
\Delta B U S_{i t}=\Phi_{i}\left(B U S_{i, t-1}-\theta_{0 i}-\theta_{1 i} H P_{i t}\right)+\delta_{11 i} \Delta H P_{i t}+\varepsilon_{i t},(3)
$$

where $\Phi_{i}=-\left(1-\lambda_{i}\right), \theta_{0 i}=\mu_{i} /\left(1-\lambda_{i}\right)$ and $\theta_{1 i}=\left(\delta_{10 i}+\delta_{11 i}\right) /$ $\left(1-\lambda_{i}\right)$.

The error-correction speed of adjustment parameter, $\Phi_{i}$, and the long-run coefficients, $\theta_{1 i}$ is of primary interest. With the inclusion of $\theta_{0 i}$, a nonzero mean of the cointegrating relationship is allowed. It is expected that $\Phi_{i}$, will be negative if the variables exhibit a return to longrun equilibrium (Blackburne \& Frank, 2007). 
The ARDL approach has been used by several researchers to analyse housing market dynamics (e.g., Bangura \& Lee, 2020) and to test the relationship between house prices and other economic and political variables (e.g., Apergis et al., 2015; Inglesi-Lotz \& Gupta, 2013).

\section{Results}

In section 3.1, we present the results of panel ARDL/PMG estimations for each house price index along with various economic sectors. In section 3.2, we perform a robustness check (by including control variables) to confirm the validity of our main findings.

\subsection{Main analyses}

\subsubsection{All house price index and business registration by sector}

Table 4 shows the estimation results for the relationship between all house price index (HP) and sub-sectoral business registration. The long-run analyse suggests that there is a positive and significant association between HP and establishment of businesses in MANUFACTURING, WHOLESALE, INFORMATION and FINANCE over the long-run. The positive relationship between house prices and business formation in these industries can be explained by housing wealth effects and the housing collateral enhancement hypotheses (e.g., Connolly et al., 2015; Kerr et al., 2015). In terms of the housing collateral enhancement hypotheses, for example, Adelino et al. (2015) show that the availability of more valuable collateral (through increased house prices) has a positive impact on the creation of small firms or selfemployment, because it provides individuals with easier access to start-up capital (through home equity line of credit financing and cash out refinancing). In our case, when house prices increase some potential Malaysian creditconstrained entrepreneurs and investors who own houses ${ }^{8}$ enter into the business of manufacturing, wholesale and retail trade, information, and communication, as well as financial and insurance. These findings are consistent with the results of "2015 Malaysia Enterprise Survey" which, for example, show that $43 \%$ of retail businesses (in the survey) face moderate to severe difficulty in getting access to external finance. Similarly, $44 \%$ of manufacturing establishments indicated that access to finance is a moderate to severe obstacle to the current operations of their businesses.

On the other hand, the findings indicate that there is a negative and significant association between HP and business formation in five sectors (UTILITY, CONSTRUCTION, TRANSPORT, ACCFOOD and REALESTATE) over the long-run. The reverse relationship between house prices and business formation in these sectors might be explained by the property investment opportunity channel introduced by Gholipour (2020) and $\mathrm{Li}$ and $\mathrm{Wu}$ (2014). In addition, it can be argued that those investors who also own residen-

\footnotetext{
8 It is noteworthy that real estate assets account for more than 90 percent of Malaysian household's wealth (Abdul Khalid, 2011).
}

tial properties may divert their capital gains in the property market to other financial asset classes (e.g., shares, bonds) instead of investing in new businesses within the UTILITY, CONSTRUCTION, TRANSPORT, ACCFOOD and REALESTATE sectors. We also find that there is an insignificant long-run link between HP and business registration for three sectors including AGRICULTURE, WATER and PROFESSIONAL. One possible explanation for this result could be the existence of a counterbalance between the positive and negative channels discussed above. While the housing wealth and collateral effects may encourage potential entrepreneurs and investors to start businesses in these sectors (AGRICULTURE, WATER and PROFESSIONAL) the negative channels (e.g., the property investment opportunity) may dampen such motivations. Generally, our results are in line with Berggren et al. (2019) who provide evidence that the impact of house prices on new business start-up differ across Swedish industries.

The possible reasons why business formation in different sectors respond differently to changes in house prices are threefold. First, increases in house prices which lead to enhancement in housing wealth and housing collateral may be enough to finance a business start-up in certain industries but may not be adequate for other industries. For example, initial fixed costs associated with the creation of a retail business are dwarfed in comparison to the fixed costs required to initiate a construction firm. Therefore, a positive change in house prices that enhances housing wealth and collateral may encourage homeowners to open a new retail shop, but it is unlikely that it can impact decisions to initiate a construction firm, ceteris paribus (of course if there is a business opportunity). In support of this finding, Adelino et al. (2015) suggest that the capital needs in certain industries are too high to be financed through property collateral and these investment requirements influence how much a given sector relies on the property collateral. Indeed, their empirical analysis finds the impact of house prices on creation of small business to be stronger in sectors in which the amount of capital needed to establish a new business is lower. Similarly, Balasubramanyan and Coulson (2013) show that there is a strong and positive association between house prices and the start-up of very small businesses, but no significant association between house prices and start-up of large firms.

Second, the levels of competition and market power of firms in each industry is different, and therefore non-financial barriers to entry of new businesses may differ across industries. Existing studies show that market and industry factors determine a new venture's decision to enter and their ensuing level of success (or failure). For example, Sandberg and Hofer (1987) find evidence that industry structure can influence new venture performance. Moreover, Bresnahan (1989) show that there is a great deal of market power in some concentrated industries, where competition is higher. Therefore, more intense competition and a less lucrative market may discourage entrepreneurs to venture into some economic sectors despite possessing sufficient capital to cover entry costs (through their housing collateral). 
Third, entrepreneurs can obtain finance from alternative sources such as venture capitalists and angel investors, and start-ups in certain sectors are more attractive to these investors. Thus, rises in house prices-and their positive impact on collateral-may not have a significant effect on venture creation in some sectors. Lyons and Kenney (2007) suggest that venture capitalists are most often attracted to start-ups in those sectors with a long history of good returns, such as information and communication technologies, and the biomedical sector, in addition to start-ups in the retail sector, which tends to deliver a steady (though much lower) rate of return. Governmentrelated investment organizations in Malaysia, such as Khazanah Nasional Berhad, can also have an impact, and this institution has made investments in sectors such as finance, communication services, IT, telecommunications, utilities, and transportation (Lyons \& Kenney, 2007). Therefore, the peculiar and specific interest of investors, both private and public, is one possible reason why the link between HP and start-up establishments remains insignificant in some sectors.

Table 4. All house price index (HP) and sub-sectoral business formation

\begin{tabular}{|c|c|c|c|}
\hline \multirow[b]{2}{*}{ Dependent variable } & \multirow{2}{*}{$\begin{array}{c}\text { Long-run } \\
\text { Log of } \\
\text { all house } \\
\text { price } \\
\text { index }\end{array}$} & \multicolumn{2}{|c|}{ Short-run } \\
\hline & & $\begin{array}{c}\text { Error } \\
\text { correction }\end{array}$ & $\begin{array}{l}\text { D. Log of } \\
\text { all house } \\
\text { price } \\
\text { index }\end{array}$ \\
\hline D.AGRICULTURE & $\begin{array}{c}0.016 \\
(0.015)\end{array}$ & $\begin{array}{c}-0.433^{\star * *} \\
(0.066)\end{array}$ & $\begin{array}{l}-0.007 \\
(0.028)\end{array}$ \\
\hline D.MANUFACTURING & $\begin{array}{c}0.170^{\star * *} \\
(0.010)\end{array}$ & $\begin{array}{c}-0.422^{* * *} \\
(0.124)\end{array}$ & $\begin{array}{l}-0.015 \\
(0.061)\end{array}$ \\
\hline D.UTILITY & $\begin{array}{l}-0.002^{* *} \\
(0.0008)\end{array}$ & $\begin{array}{c}-0.510^{* * *} \\
(0.062)\end{array}$ & $\begin{array}{c}-0.005^{* * *} \\
(0.001)\end{array}$ \\
\hline D.WATER & $\begin{array}{c}0.0008 \\
(0.0007)\end{array}$ & $\begin{array}{c}-0.550^{* * *} \\
(0.107)\end{array}$ & $\begin{array}{l}-0.005 \\
(0.005)\end{array}$ \\
\hline D.CONSTRUCTION & $\begin{array}{c}-0.083^{* * *} \\
(0.010)\end{array}$ & $\begin{array}{c}-0.317^{\star * *} \\
(0.077)\end{array}$ & $\begin{array}{c}0.092^{* * *} \\
(0.023)\end{array}$ \\
\hline D.WHOLESALE & $\begin{array}{c}0.542^{\star * *} \\
(0.155)\end{array}$ & $\begin{array}{c}-0.095^{\star * *} \\
(0.028)\end{array}$ & $\begin{array}{c}-0.100^{*} \\
(0.055)\end{array}$ \\
\hline D.TRANSPORT & $\begin{array}{c}-0.025^{* * *} \\
(0.004)\end{array}$ & $\begin{array}{c}-0.577^{* * *} \\
(0.076)\end{array}$ & $\begin{array}{c}0.051 \\
(0.037)\end{array}$ \\
\hline D.ACCFOOD & $\begin{array}{c}-0.142^{\star * *} \\
(0.020)\end{array}$ & $\begin{array}{c}-0.436^{* * *} \\
(-0.087)\end{array}$ & $\begin{array}{l}-0.009 \\
(0.067)\end{array}$ \\
\hline D.INFORMATION & $\begin{array}{l}0.005^{\star * \star} \\
(0.0003)\end{array}$ & $\begin{array}{c}-0.647^{\star * * *} \\
(0.127)\end{array}$ & $\begin{array}{l}0.021^{\star *} \\
(0.009)\end{array}$ \\
\hline D.FINANCE & $\begin{array}{l}0.003^{*} \\
(0.001)\end{array}$ & $\begin{array}{c}-1.105^{* * *} \\
(0.029)\end{array}$ & $\begin{array}{l}-0.030 \\
(0.023)\end{array}$ \\
\hline D.REALESTATE & $\begin{array}{c}-0.008^{* * *} \\
(0.002)\end{array}$ & $\begin{array}{c}-0.551^{* * *} \\
(0.076)\end{array}$ & $\begin{array}{l}-0.001 \\
(0.001)\end{array}$ \\
\hline D.PROFESSIONAL & $\begin{array}{c}0.001 \\
(0.002)\end{array}$ & $\begin{array}{c}-0.537^{\star * *} \\
(0.074)\end{array}$ & $\begin{array}{l}0.032^{* *} \\
(0.016)\end{array}$ \\
\hline
\end{tabular}

Notes: Standard errors are presented in parentheses. The ${ }^{* * *},{ }^{* *}$ and

* denote statistical significance at the $1 \%, 5 \%$ and $10 \%$, respectively. Estimation Method: Panel ARDL/PMG.
The short-run analyses show that the CONSTRUCTION, INFORMATION and PROFESSIONAL sectors respond positively to changes in HP. On the other hand, the UTILITY and WHOLESALE sectors respond negatively to changes in HP. The links between HP and business registration are insignificant for other sectors. A comparison of the long-run and short-run analysis reveals that nine out of 12 sectors respond significantly to changes in house prices in the long-run, whereas only five out of $12 \mathrm{sec}-$ tors respond to changes in house prices in the short-run. Differences in the short- and long-term impact of house prices on various sectors might be due to fact that it takes a couple of years for potential entrepreneurs and investors (who own homes) to utilize their housing collateral to start their businesses.

Finally, the error-correction speed of adjustment parameter is negative, meaning that the variables show a return to long-run equilibrium. This result is itself valuable as it confirms that any divergence between shortrun and long-run is indeed temporary as the long-run brings convergence. Overall, these results indicate that the association between house prices and business formation is not homogenous across various economic sectors.

\subsubsection{House price sub-indices and business registration by sector}

Tables 5, 6 and 7 present the results of ARDL/PMG estimations when we use the Terraced House Price Index (HP_TERRACED), Detached House Price Index (HP_ DETACHED) and Semi-Detached House Price Index (HP_ SEMIDETACHED) as independent variables, respectively. The long-run estimation results for the relationship between HP_TERRACED, HP_ DETACHED, HP_SEMIDETACHED and business registration by sector are very similar to our findings for the overall HP index, as reported in Table 4 (see long-run coefficients in Tables 5, 6 and 7). Regarding the short-run impact of house price sub-indices on business registration across various sectors, again the findings are mostly in line with the results in Table 4.

This finding suggests that including house price subindices in analyses provide little additional information to the estimation of the link between the aggregate house price index and business formation in Malaysia. This is possibly due to the very strong correlation between the aggregate house price index and its sub-indices. The pairwise correlation coefficients for the relationship between HP and HP_TERRACED, HP_ DETACHED, HP_ SEMIDETACHED are $0.98,0.84$ and 0.92 , respectively $\overline{9}$.

9 One may argue that since some detached houses are more expensive than terrace houses, we should expect to find a stronger impact of detached houses prices on business formation than terrace house prices. However, the size of detached houses is much smaller than terrace houses in Malaysia. According to Jabatan Penilaian dan Perkhidmatan Harta (2020)'s Property Stock Report, detached houses accounted for $8.4 \%$ of total existing residential properties whereas Single Storey Terraced accounted for $18.6 \%$. 
Table 5. Terraced house price index and sub-sectoral business formation

\begin{tabular}{|c|c|c|c|}
\hline \multirow[b]{2}{*}{ Dependent variable } & \multirow{2}{*}{$\begin{array}{c}\text { Long-run } \\
\text { Log of } \\
\text { terraced } \\
\text { house price } \\
\text { index }\end{array}$} & \multicolumn{2}{|c|}{ Short-run } \\
\hline & & $\begin{array}{c}\text { Error } \\
\text { correction }\end{array}$ & $\begin{array}{l}\text { D. Log } \\
\text { terraced } \\
\text { house } \\
\text { price } \\
\text { index }\end{array}$ \\
\hline D.AGRICULTURE & $\begin{array}{c}0.012 \\
(0.013)\end{array}$ & $\begin{array}{c}-0.420^{* * *} \\
(0.069)\end{array}$ & $\begin{array}{c}-0.0001 \\
(0.033)\end{array}$ \\
\hline D.MANUFACTURING & $\begin{array}{c}0.159^{* * *} \\
(0.008)\end{array}$ & $\begin{array}{c}-0.453^{* * *} \\
(0.123)\end{array}$ & $\begin{array}{l}-0.009 \\
(0.045)\end{array}$ \\
\hline D.UTILITY & $\begin{array}{l}-0.002^{* *} \\
(0.0008)\end{array}$ & $\begin{array}{c}-0.490^{* * *} \\
(0.054)\end{array}$ & $\begin{array}{c}-0.098^{* * *} \\
(0.035)\end{array}$ \\
\hline D.WATER & $\begin{array}{c}0.0009 \\
(0.0007)\end{array}$ & $\begin{array}{c}-0.540^{\star * *} \\
(0.1035)\end{array}$ & $\begin{array}{c}-0.004 \\
(0.003)\end{array}$ \\
\hline D.CONSTRUCTION & $\begin{array}{c}-0.0914^{* * *} \\
(0.012)\end{array}$ & $\begin{array}{c}-0.296^{* * *} \\
(0.068)\end{array}$ & $\begin{array}{c}0.085^{\star * *} \\
(0.030)\end{array}$ \\
\hline D.WHOLESALE & $\begin{array}{c}0.580^{* * *} \\
(0.267)\end{array}$ & $\begin{array}{c}-0.078^{\star * *} \\
(0.018)\end{array}$ & $\begin{array}{c}-0.081^{*} \\
(0.064)\end{array}$ \\
\hline D.TRANSPORT & $\begin{array}{c}-0.028^{\star * *} \\
(0.004)\end{array}$ & $\begin{array}{c}-0.551^{\star * *} \\
(0.082)\end{array}$ & $\begin{array}{c}0.049 \\
(0.341)\end{array}$ \\
\hline D.ACCFOOD & $\begin{array}{c}-0.156^{* * *} \\
(0.020)\end{array}$ & $\begin{array}{c}-0.408^{\star * \star} \\
(-0.100)\end{array}$ & $\begin{array}{l}-0.027 \\
(0.060)\end{array}$ \\
\hline D.INFORMATION & $\begin{array}{c}0.005^{\star * *} \\
(0.000)\end{array}$ & $\begin{array}{c}-0.6154^{* * *} \\
(0.126)\end{array}$ & $\begin{array}{l}0.019^{\star *} \\
(0.008)\end{array}$ \\
\hline D.FINANCE & $\begin{array}{l}0.003^{*} \\
(0.001)\end{array}$ & $\begin{array}{c}-1.098^{* * *} \\
(0.021)\end{array}$ & $\begin{array}{c}0.008 \\
(0.021)\end{array}$ \\
\hline D.REALESTATE & $\begin{array}{c}-0.007^{* * *} \\
(0.000)\end{array}$ & $\begin{array}{c}-0.545^{\star * *} \\
(0.081)\end{array}$ & $\begin{array}{c}0.000 \\
(0.002)\end{array}$ \\
\hline D.PROFESSIONAL & $\begin{array}{c}0.004 \\
(0.002)\end{array}$ & $\begin{array}{c}-0.571^{* * *} \\
(0.071)\end{array}$ & $\begin{array}{l}0.019^{\star \star} \\
(0.012)\end{array}$ \\
\hline
\end{tabular}

Notes: Standard errors are presented in parentheses. The ${ }^{* * *},{ }^{* *}$ and

* denote statistical significance at the $1 \%, 5 \%$ and $10 \%$, respectively. Estimation Method: Panel ARDL/PMG.

Table 6. Detached house price index and sub-sectoral business formation

\begin{tabular}{|l|c|c|c|}
\hline & Long-run & \multicolumn{2}{|c|}{ Short-run } \\
\cline { 2 - 4 } Dependent variable & $\begin{array}{c}\text { Log of } \\
\text { detached } \\
\text { house price } \\
\text { index }\end{array}$ & $\begin{array}{c}\text { Error } \\
\text { correction }\end{array}$ & $\begin{array}{c}\text { D. Log of } \\
\text { detached } \\
\text { house } \\
\text { price } \\
\text { index }\end{array}$ \\
\hline D.AGRICULTURE & 0.035 & $-0.454^{* * *}$ & -0.010 \\
& $(0.015)$ & $(0.062)$ & $(0.017)$ \\
\hline D.MANUFACTURING & $\begin{array}{c}0.121^{* * *} \\
(0.012)\end{array}$ & $\begin{array}{c}-0.270^{* * *} \\
(0.067)\end{array}$ & $\begin{array}{c}-0.0289 \\
(0.019)\end{array}$ \\
\hline D.UTILITY & $-0.003^{* *}$ & $-0.504^{* * *}$ & -0.001 \\
& $(0.000)$ & $(0.074)$ & $(0.000)$ \\
\hline D.WATER & 0.0001 & $-0.527^{* * *}$ & -0.001 \\
& $(0.0001)$ & $(0.099)$ & $(0.002)$ \\
\hline D.CONSTRUCTION & $-0.073^{* * *}$ & $-0.297^{* * *}$ & 0.034 \\
& $(0.009)$ & $(0.073)$ & $(0.009)$ \\
\hline D.WHOLESALE & $0.615^{* * *}$ & $-0.095^{* * *}$ & $-0.038^{*}$ \\
& $(0.228)$ & $(0.029)$ & $(0.015)$ \\
\hline
\end{tabular}

\begin{tabular}{|c|c|c|c|}
\hline \multirow[b]{2}{*}{ Dependent variable } & \multirow{2}{*}{$\begin{array}{c}\text { Long-run } \\
\begin{array}{c}\text { Log of } \\
\text { detached } \\
\text { house price } \\
\text { index }\end{array}\end{array}$} & \multicolumn{2}{|c|}{ Short-run } \\
\hline & & $\begin{array}{c}\text { Error } \\
\text { correction }\end{array}$ & $\begin{array}{l}\text { D. Log of } \\
\text { detached } \\
\text { house } \\
\text { price } \\
\text { index }\end{array}$ \\
\hline D.TRANSPORT & $\begin{array}{c}-0.021^{\star * *} \\
(0.005)\end{array}$ & $\begin{array}{c}-0.538^{* * *} \\
(0.063)\end{array}$ & $\begin{array}{c}0.005 \\
(0.006)\end{array}$ \\
\hline D.ACCFOOD & $\begin{array}{c}-0.148^{* * *} \\
(0.029)\end{array}$ & $\begin{array}{c}-0.389^{* * *} \\
(0.072)\end{array}$ & $\begin{array}{c}0.024 \\
(0.015)\end{array}$ \\
\hline D.INFORMATION & $\begin{array}{c}0.005^{\star * *} \\
(0.000)\end{array}$ & $\begin{array}{c}-0.401^{\star * *} \\
(0.122)\end{array}$ & $\begin{array}{c}0.00005 \\
(0.001)\end{array}$ \\
\hline D.FINANCE & $\begin{array}{l}0.002^{*} \\
(0.002)\end{array}$ & $\begin{array}{c}-1.085^{* * *} \\
(0.032)\end{array}$ & $\begin{array}{l}-0.004 \\
(0.016)\end{array}$ \\
\hline D.REALESTATE & $\begin{array}{c}-0.0001^{\star * *} \\
(0.000)\end{array}$ & $\begin{array}{c}-0.534^{* * *} \\
(0.077)\end{array}$ & $\begin{array}{l}-0.001 \\
(0.001)\end{array}$ \\
\hline D.PROFESSIONAL & $\begin{array}{l}-0.002 \\
(0.003)\end{array}$ & $\begin{array}{c}-0.436^{* * *} \\
(0.060)\end{array}$ & $\begin{array}{l}0.013^{\star *} \\
(0.007)\end{array}$ \\
\hline
\end{tabular}

Notes: Standard errors are presented in parentheses. The ${ }^{* * *},{ }^{* *}$ and ${ }^{*}$ denote statistical significance at the $1 \%, 5 \%$ and $10 \%$, respectively. Estimation Method: Panel ARDL/PMG.

Table 7. Semi-detached house price index and sub-sectoral business formation

\begin{tabular}{|c|c|c|c|}
\hline \multirow[b]{2}{*}{ Dependent variable } & \multirow{2}{*}{$\begin{array}{c}\text { Long-run } \\
\text { Log of } \\
\text { semi- } \\
\text { detached } \\
\text { house price } \\
\text { index }\end{array}$} & \multicolumn{2}{|c|}{ Short-run } \\
\hline & & $\begin{array}{c}\text { Error } \\
\text { correction }\end{array}$ & $\begin{array}{l}\text { D. Log } \\
\text { of semi- } \\
\text { detached } \\
\text { house } \\
\text { price } \\
\text { index }\end{array}$ \\
\hline D.AGRICULTURE & $\begin{array}{c}0.027 \\
(0.015)\end{array}$ & $\begin{array}{c}-0.446^{* * *} \\
(0.064)\end{array}$ & $\begin{array}{c}-0.012 \\
(0.023)\end{array}$ \\
\hline D.MANUFACTURING & $\begin{array}{c}0.152^{\star * *} \\
(0.012)\end{array}$ & $\begin{array}{c}-0.396^{* * *} \\
(0.093)\end{array}$ & $\begin{array}{c}0.019 \\
(0.023)\end{array}$ \\
\hline D.UTILITY & $\begin{array}{c}-0.002^{\star *} \\
(0.000)\end{array}$ & $\begin{array}{c}-0.469^{* * *} \\
(0.062)\end{array}$ & $\begin{array}{c}-0.005 \\
(0.005)\end{array}$ \\
\hline D.WATER & $\begin{array}{c}0.0009^{*} \\
(0.0005)\end{array}$ & $\begin{array}{c}-0.565^{\star * *} \\
(0.124)\end{array}$ & $\begin{array}{c}0.001 \\
(0.002)\end{array}$ \\
\hline D.CONSTRUCTION & $\begin{array}{c}-0.089^{* \star *} \\
(0.009)\end{array}$ & $\begin{array}{c}-0.364^{* * *} \\
(0.078)\end{array}$ & $\begin{array}{c}0.027 \\
(0.241)\end{array}$ \\
\hline D.WHOLESALE & $\begin{array}{c}0.505^{\star * *} \\
(0.162)\end{array}$ & $\begin{array}{c}-0.085^{* * *} \\
(0.024)\end{array}$ & $\begin{array}{c}-0.084^{*} \\
(0.038)\end{array}$ \\
\hline D.TRANSPORT & $\begin{array}{c}-0.019^{* * *} \\
(0.005)\end{array}$ & $\begin{array}{c}-0.535^{\star * *} \\
(0.052)\end{array}$ & $\begin{array}{c}0.022 \\
(0.010)\end{array}$ \\
\hline D.ACCFOOD & $\begin{array}{c}-0.162^{\star * *} \\
(0.018)\end{array}$ & $\begin{array}{c}-0.433^{* * *} \\
(0.117)\end{array}$ & $\begin{array}{c}0.178 \\
(0.039)\end{array}$ \\
\hline D.INFORMATION & $\begin{array}{c}0.005^{\star * *} \\
(0.000)\end{array}$ & $\begin{array}{c}-0.464^{\star * *} \\
(0.101)\end{array}$ & $\begin{array}{l}0.006^{\star *} \\
(0.001)\end{array}$ \\
\hline D.FINANCE & $\begin{array}{c}0.003^{\star} \\
(0.001)\end{array}$ & $\begin{array}{c}-1.102^{* * *} \\
(0.028)\end{array}$ & $\begin{array}{l}-0.019 \\
(0.011)\end{array}$ \\
\hline D.REALESTATE & $\begin{array}{c}-0.0001^{\star * *} \\
(0.000)\end{array}$ & $\begin{array}{c}-0.476^{* * *} \\
(0.091)\end{array}$ & $\begin{array}{c}0.001 \\
(0.001)\end{array}$ \\
\hline D.PROFESSIONAL & $\begin{array}{c}0.005 \\
(0.002)\end{array}$ & $\begin{array}{c}-0.553^{* * *} \\
(0.072)\end{array}$ & $\begin{array}{l}0.020^{* *} \\
(0.006)\end{array}$ \\
\hline
\end{tabular}

Notes: Standard errors are presented in parentheses. The ${ }^{* * *},{ }^{* *}$ and * denote statistical significance at the $1 \%, 5 \%$ and $10 \%$, respectively. Estimation Method: Panel ARDL/PMG. 


\subsection{Robustnes check by including control variables}

In Table 8, we run models with HP, the unemployment rate, and the population as explanatory variables, while business registration by sector is used as the dependent variable. The selection of additional explanatory variables is based on the accessibility of information for these variables for all states over the period of our study ${ }^{10}$. Employment and population are included in the estimation models because they are indicators of business opportunities in the economy (e.g., Harrison \& Hart, 1983; Hájek et al., 2015).

Table 8. All house price index (HP) and sub-sectoral business formation (with control variables)

\begin{tabular}{|c|c|c|c|}
\hline \multirow[b]{2}{*}{ Dependent variable } & \multirow{2}{*}{$\begin{array}{c}\text { Long-run } \\
\text { Log of } \\
\text { all house } \\
\text { price } \\
\text { index }\end{array}$} & \multicolumn{2}{|c|}{ Short-run } \\
\hline & & $\begin{array}{c}\text { Error } \\
\text { correction }\end{array}$ & $\begin{array}{l}\text { D. Log of } \\
\text { all house } \\
\text { price } \\
\text { index }\end{array}$ \\
\hline D.AGRICULTURE & $\begin{array}{l}-0.029 \\
(0.037)\end{array}$ & $\begin{array}{c}-0.416^{* * *} \\
(0.058)\end{array}$ & $\begin{array}{c}-0.071^{*} \\
(0.036)\end{array}$ \\
\hline D.MANUFACTURING & $\begin{array}{c}0.163^{\star * *} \\
(0.018)\end{array}$ & $\begin{array}{c}-0.413^{* * *} \\
(0.145)\end{array}$ & $\begin{array}{c}-0.053 \\
(0.065)\end{array}$ \\
\hline D.UTILITY & $\begin{array}{c}-0.005^{\star * *} \\
(0.001)\end{array}$ & $\begin{array}{c}-0.549^{* * *} \\
(0.084)\end{array}$ & $\begin{array}{c}-0.005^{\star *} \\
(0.002)\end{array}$ \\
\hline D.WATER & $\begin{array}{c}0.007^{\star *} \\
(0.003)\end{array}$ & $\begin{array}{c}-0.565^{\star * *} \\
(0.114)\end{array}$ & $\begin{array}{c}-0.010^{*} \\
(0.005)\end{array}$ \\
\hline D.CONSTRUCTION & $\begin{array}{c}-0.129^{* * *} \\
(0.013)\end{array}$ & $\begin{array}{c}-0.273^{\star *} \\
(0.122)\end{array}$ & $\begin{array}{c}0.107^{\star * *} \\
(0.024)\end{array}$ \\
\hline D.WHOLESALE & $\begin{array}{c}1.133^{* * *} \\
(0.401)\end{array}$ & $\begin{array}{c}-0.113^{* * *} \\
(0.029)\end{array}$ & $\begin{array}{l}-0.090 \\
(0.071) \\
\end{array}$ \\
\hline D.TRANSPORT & $\begin{array}{l}0.024^{\star *} \\
(0.009)\end{array}$ & $\begin{array}{c}-0.505^{* * *} \\
(0.108)\end{array}$ & $\begin{array}{c}.0485 \\
(0.053)\end{array}$ \\
\hline D.ACCFOOD & $\begin{array}{c}0.014 \\
(0.032)\end{array}$ & $\begin{array}{c}-0.352^{* * *} \\
(0.069)\end{array}$ & $\begin{array}{l}-0.025 \\
(0.104)\end{array}$ \\
\hline D.INFORMATION & $\begin{array}{l}0.004^{* * *} \\
(0.0009)\end{array}$ & $\begin{array}{c}-0.665^{\star * *} \\
(0.132)\end{array}$ & $\begin{array}{l}0.019^{* *} \\
(0.008)\end{array}$ \\
\hline D.FINANCE & $\begin{array}{c}0.008 \\
(0.005) \\
\end{array}$ & $\begin{array}{l}-1.039 \\
(0.045)\end{array}$ & $\begin{array}{r}-0.013 \\
(0.018) \\
\end{array}$ \\
\hline D.REALESTATE & $\begin{array}{c}0.0009 \\
(0.0009) \\
\end{array}$ & $\begin{array}{c}-0.527^{* * *} \\
(0.080)\end{array}$ & $\begin{array}{l}-0.002 \\
(0.001) \\
\end{array}$ \\
\hline D.PROFESSIONAL & $\begin{array}{c}0.011^{*} \\
(0.005)\end{array}$ & $\begin{array}{c}-0.567^{\star * *} \\
(0.181)\end{array}$ & $\begin{array}{c}0.002 \\
(0.028)\end{array}$ \\
\hline
\end{tabular}

Notes: Standard errors are presented in parentheses. The ${ }^{* * *},{ }^{* *}$ and * denote statistical significance at the $1 \%, 5 \%$ and $10 \%$, respectively. The control variables are: logarithm of population and unemployment rate. Estimation Method: Panel ARDL/PMG.

\footnotetext{
${ }^{10}$ We do not include GDP per capita (which is often used as a measure of economic activities and a main determinant of business formation) in the model because reliable data for GDP per capita across Malaysian states are only available from 2010. Nevertheless, we include unemployment rate which is strongly correlated with economic activities (based on the Okun's law (Okun, 1962)). For a comprehensive review of existing studies on determinants of business formation, see Davidsson and Henrekson (2002), Hájek et al. (2015), Harrison and Hart (1983) and Iacobuta and Hatmanu (2016).
}

As can be seen from Table 8, HP is positively and significantly related to business registration in manufacturing, wholesale and retail trade, information and communication, transportation and storage and professional, scientific, and technical activities in the long-run. Comparing the results shown in Table 8 with our findings in Table 4, we can conclude that the link between HP and business registration in manufacturing, wholesale, and retail trade, as well as information and communication, is robust even after including the control variables. In addition, the short-run analysis indicates that the construction and information and communication sectors respond positively to changes in houses prices.

\section{Conclusions}

Although some studies have examined the relationship between an aggregate house price index and business formation, very few empirical studies have examined the long-run and short-run link between the sub-indices of house prices and business establishments in various industries. Using data from a set of Malaysian states from 2000 to 2016, we provide evidence that the manufacturing, wholesale and retail trade, information and communication as well as the financial and insurance sectors respond positively to changes in the aggregate house price index and its sub-indices (terraced, detached and semi-detached houses). On the other hand, the accommodation and food service activities, utility, construction, transportation and storage, and real estate activities sectors exhibit negative responses to changes in house prices. For the short-run analysis, we find that changes in house prices have a positive effect on the number of business registrations in the construction, information and communication and professional, scientific, and technical activities sectors. These results lend empirical support to the results of Adelino et al. (2015) and Berggren et al. (2019), who have shown that the effect of house prices on business formation is heterogeneous across industries.

Our findings provide an implication for policymakers. Given the importance of SMEs for the Malaysian economy, and their impact on employment and the rate of growth, it is important for policymakers to have a complete understanding of the drivers of SME formation. Since house price fluctuations are significantly related to business formation in various sectors, monitoring the changes in house prices provides useful information for the purposes of forecasting business registration in Malaysia. For example, the wholesale and retail trade sector accounts for about $45 \%$ of total business registration in Malaysia over the period of our study (2000-2016). Our results show that the sector strongly responds to rises in prices of all types of residential properties in the longrun. Therefore, we should expect that a positive shock to house prices would have a favourable impact on business start-ups in the wholesale and retail trade sectors over the long-run. 
The findings of this study should be considered in light of its limitations. Due to data constraints, we only analyse data of 10 Malaysian states (excluding states in East Malaysia, Sabah, and Sarawak) and therefore generalizations of these findings should be made with caution. Further research may examine the moderating role of the level of financial literacy on the relationship between house prices and business start-up in Malaysia if data on financial literacy for each state becomes available at a later date. In addition, future studies may investigate the effect of residential property prices on business start-up at the city and district levels. This micro approach would likely provide additional insightful findings. Finally, the other limitation of our study is that we did not include comprehensive determinants of business start-up in the robustness regressions (e.g., institutional quality, business environment indicators at Malaysia states level) due to unavailability of data for these variables over time.

\section{Acknowledgements}

We would like to thank the two anonymous reviewers for their constructive and useful comments on earlier version of this paper.

\section{Author contributions}

Hassan F. Gholipour and Sabai Khin were responsible for the design and development of the data analysis and draft of the article. Angela Tan-Kantor and Heath Spong were responsible for writing the literature review and editing the final draft. All authors were responsible for data interpretation.

\section{Disclosure statement}

The authors have no competing financial, professional, or personal interests from other parties.

\section{References}

Abdul Khalid, M. (2011). Household wealth in Malaysia: composition and inequality among ethnic groups. Jurnal Ekonomi Malaysia [Malaysian Journal of Economics], 45, 71-80.

Abraham, F., \& Schmukler, S. L. (2017, October). Addressing the SME finance problem (Research and Policy Briefs, the World Bank Malaysia Hub. No. 9). https://papers.ssrn.com/sol3/papers.cfm?abstract_id $=3249560$

Adelino, M., Schoar, A., \& Severino, F. (2015). House prices, collateral, and self-employment. Journal of Financial Economics, 117(2), 288-306.

https://doi.org/10.1016/j.jfineco.2015.03.005

Apergis, A., Simo-Kengne, B. D., Gupta, R., \& Chang, T. (2015). The dynamic relationship between house prices and output: evidence from US metropolitan areas. International Journal of Strategic Property Management, 19(4), 336-345. https://doi.org/10.3846/1648715X.2015.1072857

Bangura, M., \& Lee, C. L. (2020). Housing price bubbles in Greater Sydney: evidence from a submarket analysis. Housing Studies. https://doi.org/10.1080/02673037.2020.1803802
Balasubramanyan, L., \& Coulson, E. (2013). Do house prices impact business starts? Journal of Housing Economics, 22(1), 36-44. https://doi.org/10.1016/j.jhe.2013.01.001

Berggren, B., Fili, A., \& Wilhelmsson, M. H. (2019). Homeownership and entrepreneurship: a regional and industrial analysis of house prices and startups. International Journal of Housing Markets and Analysis, 12(3), 456-473. https://doi.org/10.1108/IJHMA-01-2018-0007

Black, J., De Meza, D., \& Jeffreys, D. (1996). House prices, the supply of collateral and the enterprise economy. The Economic Journal, 106(434), 60-75. https://doi.org/10.2307/2234931

Blackburne, E. F., \& Frank, M. W. (2007). Estimation of nonstationary heterogeneous panels. The Stata Journal, 7(2), 197208. https://doi.org/10.1177/1536867X0700700204

Braun, M. (2003). Financial contractibility and asset hardness. University of California-Los Angeles.

Bresnahan, T. F. (1989). Empirical studies of industries with market power. In Handbook of industrial organization (Chapter 17, Vol. 2, pp. 1011-1057). Elsevier. https://doi.org/10.1016/S1573-448X(89)02005-4

Companies Commission of Malaysia. (2020). Registration of business. https://www.ssm.com.my/Pages/Home.aspx\#

Connolly, E., Gianni, L., \& Read, M. (2015). Housing prices and entrepreneurship: evidence for the housing collateral channel in Australia (Technical report). Reserve Bank of Australia. https://www.rba.gov.au/publications/confs/2015/connollylacava-read.html

Corradin, S., \& Popov, A. (2015). House prices, home equity borrowing and entrepreneurship. The Review of Financial Studies, 28(8), 2399-2428. https://doi.org/10.1093/rfs/hhv020

Davidsson, P., \& Henrekson, M. (2002). Determinants of the prevalence of start-ups and high-growth firms. Small Business Economics, 19, 81-104. https://doi.org/10.1023/A:1016264116508

Department of Statistics Malaysia. (2019). Small and medium enterprises (SMEs) performance 2018. https://www.dosm.gov. my/v1/index.php? $\mathrm{r}=$ column/cthemeByCat\&cat=159\&bul_id =R0Vka2RpeVJ0cUlpR3BqdjhudDZhdz09\&menu_id=TE5C RUZCblh4ZTZMODZIbmk2aWRRQT09

Gholipour, H. F. (2013). Determinants of foreign investments in residential properties: evidence from Malaysian states. International Journal of Strategic Property Management, 17(3), 317-322. https://doi.org/10.3846/1648715X.2013.822436

Gholipour, H. F. (2020). Urban house prices and investments in small and medium-sized industrial firms: evidence from provinces of Iran. Urban Studies, 57(16), 3347-3362. https://doi.org/10.1177/0042098019897887

Gholipour, H. F., Al-Mulali, U., \& Mohammed, M. A. H. (2017). Wealth effect from real estate and outbound travel demand: the Malaysian case. Current Issues in Tourism, 20(1), 68-79. https://doi.org/10.1080/13683500.2014.882886

Greene, W. H. (2008). Econometric analysis (6th ed.). Prentice-Hall. Hájek, O., Nekolová, J., \& Novosák, J. (2015). Determinants of new business formation - some lessons from the Czech Republic. Economics and Sociology, 8(1), 147-156. https://doi.org/10.14254/2071-789X.2015/8-1/11

Harding, J. P., \& Rosenthal, S. S. (2017). Homeownership, housing capital gains and self-employment. Journal of Urban Economics, 99, 120-135. https://doi.org/10.1016/j.jue.2016.12.005

Harrison, R. T., \& Hart, M. (1983). Factors influencing newbusiness formation: a case study of Northern Ireland. Environment and Planning A, 15, 1395-1412. https://doi.org/10.1068\%2Fa151395 
Hurst, E., \& Lusardi, A. (2004). Liquidity constraints, household wealth, and entrepreneurship. Journal of Political Economy, 112(2), 319-347. https://doi.org/10.1086/381478

Iacobuta, A., \& Hatmanu, M. (2016). Factors influencing new business formation [Conference presentation]. The 11th edition of the International Conference "European Integration Realities and Perspectives". http://217.73.162.40/index.php/eirp/article/view/1690

Inglesi-Lotz, R., \& Gupta, R. (2013). The long-run relationship between house prices and inflation in South Africa: an ARDL approach. International Journal of Strategic Property Management, 17(2), 188-198. https://doi.org/10.3846/1648715X.2013.807400

Jabatan Penilaian dan Perkhidmatan Harta [Valuation and Property Services Department]. (2020). Property stock report. https://napic.jpph.gov.my/portal

Kerr, S. P., Kerr, W. R., \& Nanda, R. (2015). House money and entrepreneurship (Harvard Business School Working Papers No. 15-069). Harvard Business School. https://ideas.repec.org/p/hbs/wpaper/15-069.html

Lean, H. H., \& Smyth, R. (2013). Regional house prices and the ripple effect in Malaysia. Urban Studies, 50(5), 895-922. https://doi.org/10.1177/0042098012459582

Li, L., \& Wu, X. (2014). Housing prices and entrepreneurship in China. Journal of Comparative Economics, 42(2), 436-449. https://doi.org/10.1016/j.jce.2013.09.001

Lyons, K., \& Kenney, M. (2007, December 15). Report to the World Bank on the Malaysian venture capital industry. California. https://kenney.faculty.ucdavis.edu/wp-content/uploads/ sites/332/2016/03/world-bank-malaysia_vc_report.pdf
Manova, K. (2013). Credit constraints, heterogeneous firms, and international trade. Review of Economic Studies, 80, 711-744. https://doi.org/10.1093/restud/rds036

National Property Information Centre. (2019). https://napic.jpph.gov.my/portal

Okun, A. M. (1962). Potential GNP: its measurement and significance. In American Statistical Association (Ed.), Proceedings of the business and economics statistics section (pp. 98-104). American Statistical Association.

Pesaran, M. H., \& Shin, Y. (1997, January). An autoregressive distributed lag modelling approach to cointegration analysis. Cambridge University Press. https://doi.org/10.1017/CCOL521633230.011

Pesaran, M. H., Shin, Y., \& Smith, R. P. (1997). Estimating longrun relationships in dynamic heterogeneous panels (DAE Working Papers Amalgamated Series 9721).

Pesaran, M. H., Shin, Y., \& Smith, R. P. (1999). Pooled mean group estimation of dynamic heterogeneous panels. Journal of the American Statistical Association, 94, 621-634. https://doi.org/10.2307/2670182

Robson, M. T. (1996). Housing wealth, business creation and dissolution in the UK regions. Small Business Economics, 8, 39-48. https://doi.org/10.1007/BF00391974

Sandberg, W. R., \& Hofer, C. W. (1987). Improving new venture performance: the role of strategy, industry structure, and the entrepreneur. Journal of Business Venturing, 2(1), 5-28. https://doi.org/10.1016/0883-9026(87)90016-4

Schmalz, M. C., Sraer, D. A., \& Thesmar, D. (2017). Housing collateral and entrepreneurship. The Journal of Finance, 72(1), 99-132. https://doi.org/10.1111/jofi.12468

World Bank. (2021). Enterprise surveys indicators data. World Bank Group. https://www.enterprisesurveys.org/en/data 